\title{
Drivers of Farm Households' Perceived Risk Sources and Factors Affecting Uptake of Mitigation Strategies in Punjab Pakistan: Implications for Sustainable Agriculture
}

\author{
Muhammad Amjed Iqbal ${ }^{1}$, Azhar Abbas ${ }^{1, *(1)}$, Syed Asif Ali Naqvi ${ }^{2}$, Muhammad Rizwan ${ }^{3,4,5, *}$, \\ Abdus Samie ${ }^{1}$ and Umar Ijaz Ahmed ${ }^{6}$ (D) \\ 1 Institute of Agricultural and Resource Economics, University of Agriculture, Faisalabad 38040, Pakistan; \\ amjed.iqbal@uaf.edu.pk (M.A.I.); abdussamie@uaf.edu.pk (A.S.) \\ 2 Department of Economics, Government College University Faisalabad, Faisalabad 38040, Pakistan; \\ asifalinaqvi@gcuf.edu.pk \\ 3 School of Economics and Management, Yangtze University, Jingzhou 434023, China \\ 4 Changjiang River Belt Economic and Development Research Institute, Yangtze University, \\ Jingzhou 434023, China \\ 5 Centre for Agriculture Strategy and Development (CAS-D), PMAS Arid Agriculture University, \\ Rawalpindi 46000, Pakistan \\ 6 Department of Agribusiness and Applied Economics, Muhammad Nawaz Shareef University of Agriculture \\ Multan, Multan 66000, Pakistan; umar.ijaz@mnsuam.edu.pk \\ * Correspondence: azhar.abbas@uaf.edu.pk (A.A.); rizwaneco@yangtzeu.edu.cn (M.R.); \\ Tel.: +92-347-217-3764 (A.A.); +86-131-2500-8896 (M.R.)
}

Received: 30 October 2020; Accepted: 24 November 2020; Published: 26 November 2020

\begin{abstract}
Climate change is a serious threat to agriculture in many developing countries including Pakistan. Changing pattern of climate and its extreme conditions have already led to a decline in crop productivity. However, farmers in developing countries experience risks beyond just climate change, many of which are related to policy, strategy, and factor endowments. The impact of these risks have serious implications for food security, rural livelihood, farm households' wellbeing, and, above all, their motive to adapt to these changes in the long-term. To have an in-depth knowledge of farmers' perceptions about the changing climate, this study investigates various aspects such as the determinants of perception about various risk sources and the relevant mitigation and adaptation options. To do so, 480 farmers from agriculture-dominated Punjab province were randomly selected in order for us to evaluate their awareness levels, socioeconomic dynamics that influence their perceptions, and various factors that influence their perceptions to achieve the desired findings. We applied the principle factor analysis approach to ascertain major sources and strategies based on farmers' perception and planned/practiced options. Further, regression analysis was done to evaluate the factors influencing the perception levels of farmers about risk sources. The results showed that majority of the farmers faced various risks, and were trying to adapt crop husbandry practices towards these perceived risks. Change in agricultural policies (3.96) was placed as the highest risk source, while the need for small dams/turbine schemes was the top priority for risk management strategy (mean value of 4.39). By observing the effect of farm and farmer's characteristics on risk sources and risk management strategies, it was revealed that these characteristics ominously provoked farmers' perspectives about risk sources and management strategies. The findings imply the need for coherent environmental policy that encompasses price stability, community-led adaptation campaigns, and easy/uninterrupted flows of information that enables the farming community to facilitate sustainable decision processes.
\end{abstract}

Keywords: risk perception; coping strategies; agricultural households; climate change; uncertainty 


\section{Introduction}

The real threat to agriculture emerges from abrupt changes in climatic conditions and high variability that puts an immense (negative) pressure on farming decisions, thus compromising the sustainability of farm incomes [1]. Such erratic changes, which are no doubt a great source of risk for this sector, have far reaching consequences for rural livelihoods, especially in a developing country like Pakistan, where more than $50 \%$ of the population lives in rural areas and predominantly depends on farm income to meet their daily food and fiber needs. One of the major threats to rural communities in Pakistan is increased flooding, droughts, and heat waves with severe and uneven impacts. Rural Pakistani communities are poorly equipped and hesitant to apply modern tools to counter the risk, and thus the brunt of the burden falls disproportionately on small farmers compared with larger and influential ones [2]. However, decisions and practices have their roots in the nature of risk, as well as the perceived impact when the risk is faced by the inhabitants of a particular locality [3].

Humans tend to do well when planning for risks. They consider and anticipate all likely events but still every decision includes risk and uncertainty in this uncertain world. The Chinese maxim "plans are men's but the odds are Gods" summarizes this paradox. In the developing world, people's livelihood is mainly affected by different risks that ultimately negatively impact the economy [4]. Moreover, farming is much riskier than almost any other business. Hence, risk is supposed to be an inexorable and unescapable component of life, especially for formers [5]. Nonetheless, [6] categorized risks mainly into business risk and personal risks. Further business risk involves production, market, and institutional risk.

To understand farmers' risk behavior, it is necessary to know their risk perception and their responses to these risks. As such, $[7,8]$ conducted studies about agricultural household risks and their perceptions about these risks. The two terms-i.e., risk and uncertainty-are used interchangeably, yet risk can be predictable to a certain extent, while uncertainty is an unavoidable aspect of human activity. Uncertainty includes the possibility of an event that could happen but decision makers do not expect it to happen.

Risk in farming is not only relevant for individual farmers but also for society at large. For example, risk averse farmers with the passage of time might not adopt modern technology to enhance production due to the potential risks associated with it, so there will be less probability of achieving potential yields as farmers find themselves reluctant to take risks [9]. This will ultimately affect the national production and overall welfare of society. However, planning for risks solicits higher returns, which will are sustain food production to meet the increased demand of Pakistan's rapidly growing population. Therefore, progress is dependent on planning for risks. Continuity of the farming business and welfare of the farm family may depend upon risk management. Such an outcome partly corresponds to sustainability in agriculture vis-à-vis 'economic feasibility', 'economic viability', and 'temporal stability' $[10,11]$. Farm advisors should also recognize that risk and risk aversion can affect farm management decisions and outputs. Agricultural research workers, especially those working in farm development, need to focus more on risk. For policy makers and planners, it is necessary to account for farmers' risk response when setting programs and policies directly related to risk [12].

Sustainable agriculture focuses on the stability of productivity per unit of inputs in order to ensure food security and sustained living among rural communities. At the same time, it seeks to develop and access technologies and practices to ensure minimal environment impacts and the health of farmers [13]. This definition of sustainable agriculture warrants a range of steps and stimuli to confront the rapid population growth in the developing world [10,14]. Other challenges to achieve sustainability in farming come from farming communities' inability to anticipate risks and abrupt variations in the sociopolitical and institutional setups, which may mar their ability to cope with such disruptions $[15,16]$. With this background, contemplating risk sources and their management along with various drivers of uptake and perception would help draw agriculture policy implications. Herein, our hypothesis is that farmers possess different perceptions for different risk sources. Further, their response to such risk stimuli varies considerably given a set of socio-demographic, geophysical, 
and institutional features. The particular research questions addressed by this work are narrated in Section 3.

\subsection{Risk Management in Agriculture: Literature Review}

Risk management in agriculture is an innovative approach used to manage agricultural risks at the farm level. It encourages farmers to be proactive so that they can enhance their ability to assess, prepare, and adapt to risks. Many socioeconomic, progressive, and risk-avoiding factors play a role when farmers develop their risk management tactics $[17,18]$. Similarly, risk assessment is the basic element of risk management. Okinawa [19] describes three basis types of risk management strategies: prevention, mitigation, and coping. Prevention includes training, education, extension services, input provision, etc., while mitigation includes crop insurance, crop diversification, mixed farming. Coping includes hedging, pulling children out of school, off-farm work, borrowing, and selling assets. It is the responsibility of the farm operator to select an appropriate risk strategy considering their financial situation. Moreover, Ayinde [20] acknowledged risk management as a method of playing with uncertainty. A process of risk management can be categorized into risk identification, risk analysis, risk evaluation, and risk treatment. These are the steps that can be accomplished in a routine and cyclical way. Similarly, Holzmann and Jorgensen [21] proposed that a commonly used element for risk management is risk mapping.

Similarly, Arshad et al. [22] and Mahmood et al. [23] showed that Pakistani agriculture has survived severe shocks brought about by climate change, i.e., droughts and floods in both irrigated and rainfed areas. They further showed that these risks were widespread in terms of frequency and intensity, causing major crops yields, such as rice and wheat. However, farmers are sparingly aware of the intensity of the onset of these extreme events, and they are typically slow to react.

In their work, Akcaoz and Ozkan [24] divided farmers into three types: risk averse, risk neutral, and risk taker. Risk averse farmers perceive changing government policies as the most important source of risk, while considering financial resources and adjustments as the most important factor for risk management. Risk neutral farmers view changing input and output prices as the most important risk source and, hence, they adopt the strategy of working outside the farm, investing in off-farm ventures to cope with risk. In the recent past, many studies have looked at farmers' risk perception and risk management strategies in Europe and the USA alike [25-27]. These studies were very beneficial and used as a data source for policy makers and risk management professionals. However, such studies are hard to find for developing countries, especially Pakistan.

Managing risk in agriculture through integrated efforts and resilience building could pave the way for creating more sustainable agricultural systems [3,28,29]. As noted by Wheeler [30], risk identification and resultant adaptation can successfully reduce the adverse impacts of changing climate change by enhancing the possibility of positive outcomes in crop productivity. Furthermore, resource constraints and institutional lapses may lead to a compromised food security situation and a low level of risk adaptation, thus making it hard to run agriculture on sustained footing [31-33]. In their work, Raymond et al. [34] and Wang et al. [35] showed the importance of having vibrant institutional and policy support for effective adaptation risk sources, such as climate change, to ensure sustainable rural living. These studies highlight the need to work on evaluating risk sources and corresponding management options to promote food security, rural livelihoods, and effective adaptation to climate change.

\subsection{Risk Profile of Pakistan}

Pakistan's economy is agro-based. Currently, $38 \%$ of the total labor force is involved in agriculture and its share in the country's gross domestic product reached up to $18.5 \%$ [36]. The performance of the agriculture sector fell in the last few years as a result of climate change. This situation presents challenge to Pakistan's agriculture by threatening water availability and environmental policy, while, at the same time, posing implications for food security. Moreover, the agricultural industry is riskier 
than almost any other Pakistani industry. Environmental degradation, price instability, and lack of information are the main reasons for the uncertainty of farm incomes in Pakistan (Bryan et al., 2013). For Pakistani agriculture, all of these challenges add to injury caused by floods, pests, unusual rains, and disease outbreaks, thus increasing risk level for farmers in the country. This is why the World Bank included Pakistan in its 12 highly-exposed countries to climatic variability $[37,38]$.

In the last couple of years, Pakistan, and especially the Punjab province, have been exposed to numerous risks, such as floods and rainstorms. In the recent past (i.e., 2014, 2013, 2012, and 2010), Punjab has experienced continuous flooding which upset the agricultural industry [39]. Similarly, farmers using many inputs (agrochemicals) are also exposed to experience risks [40]. There are many other factors such as climate variability, geographical location, demographic conditions, price fluctuation, international market shocks, institutional structures, and government policies, etc. that can cause uncertainty for farm income and affect farmers' decision-making [41]. A lack of information is also a reason for dwindling farm income and uncertainty in produce.

Farmers need to be equipped with the latest information on different risk sources and curative strategies of these risks. Hence, there is a dire need for studies to address the risk sources and risk management strategies implemented by agricultural households in Pakistan. The present study seeks to fill this knowledge gap. Overall, the purpose of this study is to explore different risk sources and risk management strategies used by agricultural households, their perception about risks, and their relationship between farm and farmer's characteristics and risk sources and risk management strategies.

\section{Materials and Methods}

\subsection{Study Area}

The study was carried out in the Punjab province, Pakistan. It is the most populous and second largest province area-wise. It is the most fertile agricultural region in the country and has a main role in the country's economy. It is geographically located approximately at $30^{\circ} 00 \mathrm{~N}, 70^{\circ} 00 \mathrm{E}$ in the semiarid lowlands zone [42]. Overall, $56.2 \%$ of the total cultivated area accounts for the Punjab province and, similarly, 53\% of the total agricultural gross domestic product (PBS, 2011) [43]. It receives 50-75\% of its rainfall during the monsoon season [44]. Over the last few years, Punjab has suffered from severe floods and abnormal weather conditions. As such, there is a need to educate farmers about different risks.

\subsection{Sampling Procedure and Data}

Respondents were selected through a multi-stage random sampling technique. Data were collected for the cropping year 2018-2019. A total of 480 farmers in Punjab were interviewed. Initially, we selected the Punjab province purposively. Then, in the 2nd stage, 6 districts (i.e., Khanewal, Vehari, Bahawalpur, Bahawalnagar, Muzaffar Garh, and Rajan Pur) were selected (see Figure 1). In the next stage, from each selected district, 80 respondents were chosen for data collection through random sampling. A well-structured questionnaire was used to collect data regarding farmer's perception about different risk sources, management strategies, detail of farm inputs and outputs, farmer's knowledge about climatic changes, their limitations about adaptation, and the socioeconomic characters of farmers. Insights for constructing our questionnaire were taken from a similar work [45-47]. For accuracy, we involved the opinions of educated and respected local leaders and representative from the agricultural department. To avoid missing any important elements, we performed and trained a pretest for the questionnaire. 


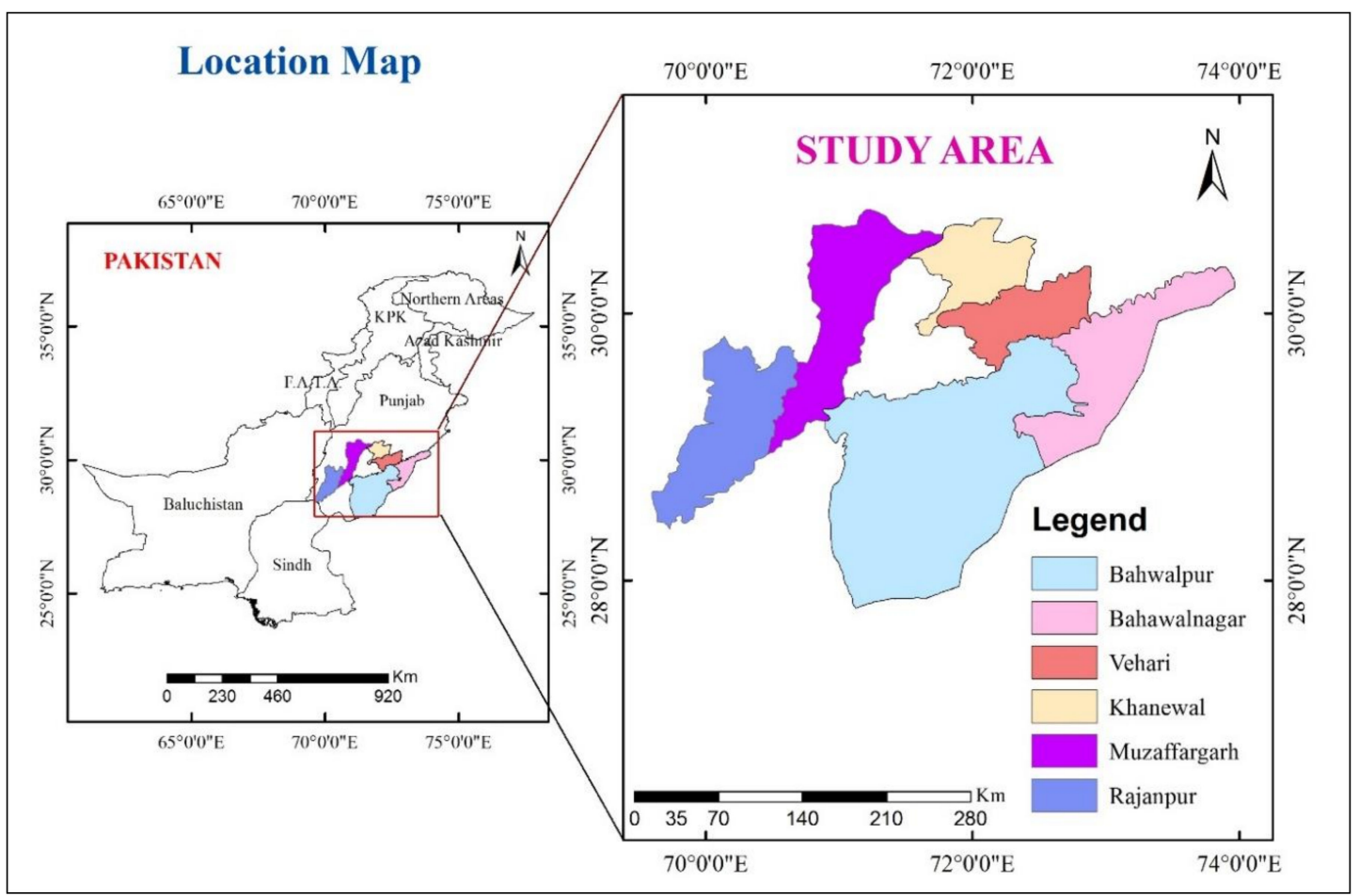

Figure 1. Study area selected for the present study.

\section{Research Questions and Analytical Procedure}

The present study sought to answer the following questions: (i) what is the risk profile in terms of the nature and extent of risks (and their sources) faced by Punjabi farmers?; (ii) what are the implemented or perceived strategies useful for coping with risks?; (iii) how is perception about various risk sources affected by different socioeconomic, demographic, and geophysical features?; and (iv) how are various risks mitigated coping strategies influenced by a range of socioeconomic, demographic, geophysical, institutional, and information-related factors.

The SPSS statistical program package was used to undertake all computations. Initially, farmers' perceptions regarding risk sources and risk management strategies were analyzed using descriptive statistical analysis. The technique of common factor analysis $[41,48]$ was used to make the information in a reduced number of factors. Factor analysis is a statistical method used to learn the dimensionality of a set of variables. In this method, latent variables represent unobserved constructs and are referred to as factors or dimensions. Confirmatory factor analysis (CFA) is a part of structural equation modelling (SEM) but can also be used for a variety of purposes, such as psychometric evaluation, the detection of method effects, construct validation, evaluation of measurement invariance, and convergent validity [49].

Confirmatory factor analysis is a tool used to establish the validity and reliability of a scale [50]. For this purpose, we used CFA to make the study more scientific and accurate. The factor analysis model shows variation and covariation in a set of observed continuous variables y $(j=1$ to $p)$ as a function of factors $\eta(k=1$ to $m)$ and residuals $\varepsilon(j=1$ to $p)$. For person $i$,

$$
\begin{gathered}
Y_{i 1}=V_{1}+\lambda_{11} \eta_{i 1}+\lambda_{12} \eta_{i 2}+\ldots+\lambda_{1 k} \eta_{i k}+\ldots \lambda_{1 m} \eta_{i m}+\varepsilon_{i 1} \\
Y_{i j}=V_{j}+\lambda_{j 1} \eta_{i 1}+\lambda_{j 2} \eta_{i 2}+\ldots+\lambda_{j k} \eta_{i k}+\ldots+\lambda_{j m} \eta_{i m}+\varepsilon_{i j} \\
Y_{i p}=V_{p}+\lambda_{p 1} \eta_{i 1}+\lambda_{p 2} \eta_{i 2}+\ldots+\lambda_{p k} \eta_{i k}+\ldots+\lambda_{p m} \eta_{i m}+\varepsilon_{i p}
\end{gathered}
$$

where $V_{j}$ is the intercept, $\lambda_{j k}$ is the factor loading, $\eta_{i k}$ are factor values, and $\varepsilon_{i j}$ are residual values with zero means and correlations of zero with the factors. 
The model in matrix form is

$$
Y_{i}=V+\Lambda \eta_{i}+\varepsilon_{i}
$$

Hence, $V$ is the vector of intercept $v_{j}, \Lambda$ is the matrix of factor loading $\lambda_{j k}, \psi$ is the matrix of factor variances/covariance, and $\Theta$ is the matrix of residual variances/covariance.

With the population covariance matrix of observed variables $\Sigma$,

$$
\Sigma=\Lambda \Psi \Lambda^{\prime}+\Theta
$$

the factor pattern is $\Lambda$, the factor structure: is $\Lambda^{*} \Psi$, the Heywood case is $\theta j j<0$, the factor score is $\hat{\eta}_{I}$, the factor determinacy is the quality of factor scores with a correlation between $\eta_{i}$ and $\hat{\eta}_{\mathrm{i}}$.

A criterion (eigenvalue $\geq 1$ ) was used as a guideline to decide how many factors needed to be eliminated. Risk sources and risk management strategies were divided into different factors according to a rotated component matrix table or orthogonal varimax rotation table. Standardized factor scores for each farmer were also used in regression. The Kaiser-Mayer-Olkin (KMO) value, which is a measure of sampling adequacy, was 0.864 for risk sources and 0.762 for risk management strategies. Both values were more than 0.70, showing that the correlation arrangement was compact and the factor analysis was suitable. In the factor analysis technique, loading values higher than 0.30 were reflected as significant factors, while loading values more than 0.40 were judged as more significant. Loading values greater than 0.50 were considered very significant [51]. In this study, a factor loading value higher than 0.40 was used to illustrate an important factor.

The ordinary least square (OLS) regression model was applied for connotation among the farm and farmers' characteristics, as well as to risk sources and risk management strategies.

\section{Results and Discussion}

Respondents were divided with respect to age, years of education, farming experience, and total farming area. These variables were indicative of farmers' thinking about how to deal with different risk sources for crop and how those risks can be managed. Our study shows that the average number of years of education was 7 and average farming experience was 24 years. In addition, 195 farmers had an income that was at last $40.6 \%$ dependent on farming. Different characteristics of farmers are presented in Table 1.

Table 1. Socioeconomic characteristics of farm households.

\begin{tabular}{lc}
\hline Characteristics & Total Respondents $(\boldsymbol{n = 4 8 0})$ \\
\hline Full-time farmers & 285 \\
Part time farmers & 195 \\
Age (average) & 46.84 \\
Family Size (average) & 7.79 \\
Average farm size (acre) & 17.19 \\
Farming Experience (years) & 24.04 \\
No. of years of education & 7.33 \\
Farm gross monthly income (PKR) & 55438.92 \\
\hline
\end{tabular}

\subsection{Farmer's Perception of Various Risk Sources}

The response of farmers was considered for 19 risk sources. Table 2 shows the mean and standard deviation for each risk source, which was calculated from the farmer's perception for each of these.

The risk sources are given in descending order with regard to the importance rendered by the farm households. Changes in agricultural policies was the highest risk source. The standard deviation of changes in agricultural policies was less than 1, showing that agricultural households accepted this to be true. Farmers' perceptions were sound, because, unfortunately, public policy is inconsistent, especially vis-à-vis enhancing agricultural productivity and improving the living standard of farmers. 
Akcaoz and Ozkan [24] also found that changes in government and agricultural policy was a prominent risk source while considering the plight of the farming community.

Table 2. Risk sources reported in the study area (Mean scores and standard deviation ( 1 = strongly disagree, 5 = strongly agree).

\begin{tabular}{lccc}
\hline Risk Sources & Mean & Std. Deviation & Ranking \\
\hline Change in agricultural policies & 3.96 & 0.55 & 1 \\
Price of farm equipment & 3.95 & 0.36 & 2 \\
Lack of farmers' cooperatives & 3.94 & 0.57 & 3 \\
Supply of private capital & 3.91 & 0.42 & 4 \\
Human health problem & 3.91 & 0.90 & 5 \\
Transportation issues & 3.90 & 0.96 & 6 \\
Supply of inputs & 3.84 & 0.96 & 7 \\
Difficulties in finding labor & 3.80 & 0.93 & 8 \\
Lack of information sources & 3.69 & 1.24 & 9 \\
Fluctuation in product prices & 3.65 & 1.72 & 10 \\
Prices of inputs & 3.55 & 0.93 & 11 \\
Severe weather conditions & 3.40 & 0.72 & 12 \\
Crop disease & 3.39 & 1.16 & 13 \\
Production uncertainty & 3.32 & 1.20 & 14 \\
Inadequate extension services & 3.24 & 1.01 & 15 \\
Lack of contract growing & 3.23 & 0.97 & 16 \\
Excessive rainfall & 3.07 & 1.09 & 17 \\
Insufficient family labor & 2.90 & 1.47 & 18 \\
\hline
\end{tabular}

The price of farm equipment was the second important risk source, with a mean value 3.95 by farmers. Farm equipment is an input needed for crop production. The price of farm equipment was studied as a risk source by Ahsan [48] and was reported as the second most important risk source by Akcaoz and Ozkan [24].

The mean value for the lack of farmers' cooperation was 3.94, which was ranked as the third most important risk source. In the study area, there was a high need for farmers' cooperation to highlight problems. The next important risk source was the supply of private capital (mean of 3.91). Furthermore, problems related to human health was risk source with a mean value of 3.91. Ahsan [48] reported that the supply of private capital was an important risk source for Bangladeshi shrimp farmers, while Bergfjord [49] indicated it as an important risk factor for fish farmers. Akcaoz and Ozkan [24] reported the health problems were an important risk factor for farmers in Turkey. Lien et al. [26] noted that family member's health situations were a risk source for farmers in Norway. Changes in the supply of private capital and human health problems caused a variation crop yield, as it is necessary for farmers to have sufficient capital to run different operations on a farm, especially if members of the household are in poor health.

Transportation issues and supply of inputs were considered as the next most important risk sources. Overall, farming in Pakistan is highly impacted by the transportation issues due to the instability of petrol and diesel prices, as well as other relevant taxes. On the other hand, the availability of different inputs at the required time is a big challenge for farmers. This is because there is shortage of fertilizer, seeds, and other inputs, and farmers have to buy these inputs for high costs, causing a financial burden. Bergfjord [49] indicated that transportation issues, prices of feed, and the supply of production factors as risk sources for the aquaculture farmers in Norway. Other risk sources with mean values included difficulties in finding labor (3.80), lack of information (3.69), fluctuation in product prices (3.65), input prices (3.55), severe weather conditions (3.40), severe onsets of crop diseases (3.39), production uncertainty (3.32), inadequate extension services (3.24), lack of contract growing (3.23), excessive rainfall (3.07), and insufficient family labor (2.90).

Five factors were obtained through factor analysis for these 19 risk sources using principle component extraction. These five factors had eigenvalues greater than 1 with a total variance of $64.88 \%$ 
(in the social sciences, a variance of $\geq 59.85$ is considered satisfactory) [52]. Ahsan [48] calculated a total variance of 59.85 for shrimp farmers in Bangladesh. Table 3 shows five factors and their respective loading items (i.e., values of $>0.40$ ). The value of Bartlett's test of sphericity was also highly significant. Factors 1 to 5 were as follows: (i) labor and market information, (ii) production constraints, (iii) institutional constraints, (iv) financial constraints, and (v) natural constraints. The labor and market information factor had high loadings on difficulties in finding labor, insufficient family labor, human health problems, excessive rainfall, input supply, product price fluctuation, transportation issues, lack of information sources, and input price. Factor 2 had an association with production uncertainty, cotton disease, lack of contract growing, and inadequate extension services. These variables were related to production and were named as production constraints. Factor 3 consisted of changes in agricultural policies and lack of farmer cooperation, and thus was entitled as institutional constraints. Factor 4 belonged to the supply of private capital and price of farm equipment, and thus was named financial constraints. The last factor (factor 5) had high loadings on severe weather conditions, so it was called natural constraints.

Table 3. Factor loadings of risk sources.

\begin{tabular}{|c|c|c|c|c|c|c|}
\hline \multirow{3}{*}{$\begin{array}{l}\text { Bartlett's Test of Sphericity: } \\
\text { Risk Sources }\end{array}$} & \multicolumn{6}{|c|}{ Approx. Chi-Square $=4722.636$} \\
\hline & \multirow[t]{2}{*}{ Means } & \multicolumn{5}{|c|}{ Factors } \\
\hline & & 1 & 2 & 3 & 4 & 5 \\
\hline Changes in agricultural policies & 3.96 & -0.002 & 0.106 & 0.829 & -0.209 & -0.108 \\
\hline Price of farm equipment & 3.95 & -0.056 & -0.028 & 0.226 & 0.693 & 0.06 \\
\hline Lack of farmers' cooperatives & 3.94 & 0.082 & -0.073 & 0.775 & 0.31 & 0.075 \\
\hline Supply of private capital & 3.91 & 0.002 & -0.02 & -0.169 & 0.774 & -0.075 \\
\hline Human health problem & 3.91 & 0.876 & 0.062 & 0.031 & -0.08 & -0.009 \\
\hline Transportation issues & 3.90 & 0.853 & 0.057 & -0.064 & 0.149 & 0.116 \\
\hline Supply of inputs & 3.84 & 0.85 & 0.106 & 0.048 & 0.088 & 0.012 \\
\hline Difficulties in finding labor & 3.80 & 0.934 & 0.076 & 0.003 & 0.069 & 0.085 \\
\hline Lack of information sources & 3.69 & 0.766 & -0.021 & 0.018 & -0.051 & -0.003 \\
\hline Fluctuation in product prices & 3.65 & -0.929 & 0.095 & -0.051 & 0.058 & 0.134 \\
\hline Prices of inputs & 3.55 & -0.637 & 0.186 & 0.14 & 0.166 & 0.27 \\
\hline Severe weather condition & 3.40 & 0.053 & -0.02 & -0.099 & 0.083 & 0.874 \\
\hline Crop disease & 3.39 & 0.113 & 0.702 & -0.121 & 0.085 & 0.049 \\
\hline Production uncertainty & 3.32 & 0.046 & 0.713 & -0.03 & 0.079 & -0.117 \\
\hline Inadequate extension services & 3.24 & 0.187 & 0.449 & 0.074 & -0.1 & 0.066 \\
\hline Lack of contract growing & 3.23 & -0.134 & 0.732 & 0.12 & -0.119 & 0.163 \\
\hline Excessive rainfall & 3.07 & 0.802 & 0.371 & -0.037 & -0.138 & 0.175 \\
\hline Insufficient family labor & 2.90 & 0.654 & 0.186 & 0.124 & -0.014 & 0.054 \\
\hline Eigenvalues & & 6.182 & 2.232 & 1.491 & 1.368 & 1.037 \\
\hline Percentage of the total variance & & 32.084 & 11.233 & 7.740 & 7.381 & 6.350 \\
\hline Cumulative percentage of total variance & & $32 / 084$ & 43.318 & 51.058 & 58.438 & 64.788 \\
\hline
\end{tabular}

Note: Factor loadings $>0.4$ are shown in bold. The names of factors for 1, 2, 3, 4, and 5 are labor and market information, production, institutional, financial, and natural constraints, respectively.

\subsection{Perceived/Implemented Risk Management Strategies}

Risk management strategies were arranged under 17 main variables like small dams, off-farm income sources, and others, as shown in Table 4.

Farmers declared small dams/turbine schemes with a mean value of 4.39 as the greatest risk management strategy. This is justifiable because, over the past several years, Pakistani farmers suffered from drought and floods that were exacerbated by government and farm mismanagement. There is a need to increase water storage capacity at the national and farm level. Many months throughout the year, farmers suffer from water shortage, and sometimes to face excessive rainfall and flood-like conditions. Due to the fact that there are no mini-dams in the vicinity of farms, as well as poor storage capacity at the provincial level, the surplus water goes wasted. For this reason, they suffer water 
shortage during peak water season. In a recent study, Qasim and Rizwan et al. $[18,53]$ reported small dams/turbine schemes as one of the most important risk management strategies.

Table 4. Perceived/implemented management strategies to tackle risks faced by respondent farmers (mean scores and standard deviation ( 1 = strongly disagree, $5=$ strongly agree).

\begin{tabular}{lccc}
\hline Risk Strategies & Mean & Std. Deviation & Ranking \\
\hline Small dams/turbine scheme & 4.39 & 0.93 & 1 \\
Off-farm income sources & 4.24 & 0.63 & 2 \\
Production diversity & 4.22 & 0.95 & 3 \\
Up to date market information & 4.04 & 0.39 & 4 \\
Providing training/getting training & 4.02 & 0.38 & 5 \\
Growing more than one crop & 3.97 & 0.40 & 6 \\
Adopt new technology & 3.96 & 0.35 & 7 \\
Assurance of bank loan & 3.92 & 0.55 & 8 \\
Contract farming & 3.88 & 0.57 & 9 \\
Preventing disease & 3.80 & 0.64 & 10 \\
Personal insurance & 3.77 & 1.69 & 11 \\
Maintaining feed/inputs reserves & 3.76 & 0.61 & 12 \\
Timely supply of inputs & 3.53 & 0.97 & 13 \\
Maintaining good relationship & 3.49 & 0.72 & 14 \\
with government & 3.41 & 0.73 & 15 \\
Stock of machinery & 3.36 & 0.65 & 16 \\
Security safeguarding & 2.53 & 0.73 & 17 \\
Growing more varieties & & &
\end{tabular}

Off-farm income sources (4.24) were ranked as the second greatest risk management strategy. Farmers in the study area, due to their low purchasing power, suffered from financial deficiency. To fulfill the ongoing expense of farming, having off-farm sources of income is helpful to safeguard financial hardships. Akcaoz and Ozkan [24] conducted a similar study among farmers in Turkey and Lien et al. [26] stated that investing in off-farm incomes sources a key risk management strategy.

Production diversity (4.22) and up-to-date market information (4.04) were the highest next risk management strategy. Aditto et al. [54] made a similar observation and found gaining/accessing market information as an important risk management strategy for farmers in developing countries. Qasim [53] also found that up-to-date market information and production diversity are considered important risk management strategies by farmers.

Providing training (4.02) and growing more than one crop (3.97) were other risk management strategies perceived and implemented by farmers. Ahsan [48] conducted a study on Bangladeshi shrimp farmers and found that training provisions for farmers is an important strategy for managing risk. Adopting new technologies (3.96) and ensuring bank loans (3.92) have been documented to be the next most important risk management strategies. Ahsan and Roth [55] affirmed the adoption of new technology as a significant risk management strategy among fish farmers in Denmark. Contract farming and preventing diseases are other risk management strategies. The majority of farmers in the study area rely on contract farming in the sense that they buy fertilizer, seed, and other inputs from middlemen or commission agents on credit and are required to sell their produce to the same agent at harvest. In this way, farmers can manage their expenses.

Other risk management strategies with their means values (in descending order) include personal insurance (3.77), maintaining feed/input reserve (3.76), timely supply of inputs (3.53), maintaining good relationships with the government (3.49), stock of machinery (3.41), security safeguarding (3.36), and growing more varieties (2.53).

As shown in Table 5, a factor analysis was applied to these 17 risk management strategies. Five factors were acquired with an eigenvalue above 1 and a total variance of $74.43 \%$. This means that these five factors explain $74.43 \%$ of the variance. These factors also had significant value of 
Bartlett's test of sphericity. These factors were capital management, credit management, research and development intervention, information management, and diversification.

Table 5. Factor loading for risk management strategies.

\begin{tabular}{|c|c|c|c|c|c|c|}
\hline \multirow{3}{*}{$\begin{array}{l}\text { Bartlett's Test of Sphericity: } \\
\text { Risk Management Strategies }\end{array}$} & \multicolumn{6}{|c|}{ Approx. Chi-Square $=6083.718$} \\
\hline & \multirow[t]{2}{*}{ Means } & \multicolumn{5}{|c|}{ Factors } \\
\hline & & 1 & 2 & 3 & 4 & 5 \\
\hline Small dams/turbine scheme & 4.39 & 0.901 & 0.012 & 0.008 & -0.014 & 0.26 \\
\hline Off-farm income sources & 4.24 & 0.712 & 0.117 & 0.062 & 0.037 & 0.175 \\
\hline Production diversity & 4.22 & 0.694 & 0.26 & -0.102 & -0.062 & 0.546 \\
\hline Up to date market information & 4.04 & 0.121 & 0.13 & -0.033 & 0.897 & 0.003 \\
\hline Provide training & 4.02 & 0.094 & -0.282 & 0.813 & 0.055 & -0.135 \\
\hline Growing more than 1 crop & 3.97 & -0.129 & -0.45 & 0.421 & 0.121 & 0.646 \\
\hline Adopt new technology & 3.96 & 0.003 & 0.2 & 0.873 & -0.018 & 0.067 \\
\hline Assurance of bank loan & 3.92 & 0.042 & 0.696 & 0.072 & 0.311 & -0.073 \\
\hline Contract farming & 3.88 & -0.104 & 0.611 & -0.109 & -0.157 & 0.182 \\
\hline Prevent disease & 3.80 & 0.812 & 0.133 & 0.065 & 0.077 & 0.038 \\
\hline Personal insurance & 3.77 & 0.875 & 0.016 & -0.047 & -0.143 & 0.334 \\
\hline Maintain feed/inputs reserves & 3.76 & 0.783 & -0.273 & 0.014 & -0.062 & -0.077 \\
\hline Timely supply of inputs & 3.53 & 0.936 & -0.064 & 0.026 & -0.093 & 0.126 \\
\hline Maintain Good relationship with govt & 3.49 & -0.394 & -0.259 & 0.129 & 0.747 & -0.281 \\
\hline Stock of spare parts & 3.41 & -0.525 & 0.516 & 0.031 & -0.275 & -0.083 \\
\hline Security safeguarding & 3.36 & -0.702 & 0.028 & -0.09 & -0.052 & -0.03 \\
\hline More Varieties & 2.53 & -0.31 & -0.211 & 0.201 & 0.282 & -0.778 \\
\hline Eigenvalues & & 6.15 & 2.381 & 1.616 & 1.425 & 1.081 \\
\hline Percentage of total variance & & 34.053 & 10.316 & 10.041 & 10.022 & 10.007 \\
\hline Cumulative percentage of total variance & & 34.053 & 44.369 & 54.410 & 64.432 & 74.439 \\
\hline
\end{tabular}

Note: Factor loadings $>0.40$ are shown in bold. The names of risk management strategies factors are capital management, credit, research and development, information management, and diversification, which are named as $1,2,3,4$, and 5, respectively.

Factor 1 had higher loadings on timely supply of inputs, small dams/turbine scheme, personal insurance, preventing disease, maintaining feed/input reserve, off-farm income, security safeguarding, production diversity, and stock of machinery. Hence, it was named capital management.

Factor 2 was determined as credit management, which includes the variables related to assurance of bank loan and contract farming. Factor 3 had high loadings on providing training and adopting new technology, and this was named research and development. Factor 4 was related to up-to-date market information and maintained good relations with government bodies; hence, it was titled information management. Lastly, factor 5 was called diversification because it was associated with more crop varieties.

\subsection{Drivers of Perceived Risk Sources}

To explore the relationship between farmers' socioeconomic characteristics and perception of risk source elements attained from factor analysis, the OLS multiple regression model was used. Overall, all models were significant as f-value. Likewise, most variables entered in the models were significant with any corresponding dependent variable. The regression coefficient and goodness of fit are given in Table 6. Further, it was observed that the $R^{2}$ value and adjusted $R^{2}$ was low in some models. These findings were confirmed in other studies related to risk perception $[25,56]$. These authors reasoned that it was due to different perceptions of risk sources and risk management strategies from respondent to respondent. Considering each model, labor and market information was significantly influenced by the eight variables. Farmers located near the main city, farmers with a large farming area, farmers with more cotton growing experience, and farmers who sold their produce to agents or middlemen showed a positive relationship with this risk factor. Full-time farmers considered 
the labor and market information risk source to be more important. However, part-time farmers, farmers with more overall monthly income, and farmers without a successor perceived this risk source to be less important. Ahsan et al. [48] found farming experience to be a significant factor for perceived risk source. For the risk source factor related to production constraints, eight variables were determined to be significant. Among these, seven variables included education, age, total farming area, cotton growing experience, family size, farmers having successor, and farmers who sell their produce to agents considered production risk more important, whereas farmers located near a city considered this factor to be less important. Dairy farmers in Norway considered production or yield as an important risk source [25].

Table 6. Regression results between farm and farmer characteristics and risk source factors.

\begin{tabular}{|c|c|c|c|c|c|}
\hline Independent Variables & $\begin{array}{l}\text { Labor and Market } \\
\text { Information }\end{array}$ & Production & Institutional & Financial & Natural \\
\hline No. of years of education & $* * *-0.041$ & $* * * 0.046$ & -0.003 & $* * * 0.044$ & $* * 0.033$ \\
\hline Farming Experience & -0.016 & -0.038 & -0.012 & 0.009 & * -0.015 \\
\hline Age & 0.008 & $* * * 0.022$ & 0.001 & -0.001 & 0.010 \\
\hline Distance from main city & $* * 0.046$ & $* *-0.025$ & $* * * 0.048$ & 0.001 & $* * *-0.032$ \\
\hline Full-time farmer ${ }^{a}$ & $*-0.205$ & 0.005 & -0.009 & -0.103 & 0.048 \\
\hline Total farming area & $* * * 0.048$ & $* 0.020$ & -0.008 & 0.000 & $* * 0.025$ \\
\hline Cotton growing experience & $* * * 0.015$ & $* 0.010$ & $* * * 0.030$ & 0.004 & 0.001 \\
\hline Family size & 0.014 & $* * * 0.078$ & $* * *-0.113$ & 0.002 & -0.003 \\
\hline $\begin{array}{l}\text { Agriculture as primary source } \\
\text { of income }\end{array}$ & 0.010 & 0.031 & 0.096 & $* 0.212$ & 0.054 \\
\hline Household monthly income & $* * *-1.726 \times 10^{-5}$ & $-4.474 \times 10^{-6}$ & $5.051 \times 10^{-6}$ & $-4.703 \times 10^{-7}$ & $-6.137 \times 10^{-6}$ \\
\hline Having successor ${ }^{c}$ & $* *-0.191$ & ** 0.225 & 0.114 & ** 0.230 & 0.055 \\
\hline Sale to agent or middleman $\mathrm{d}$ & $* * * 0.272$ & $* * * 0.263$ & 0.089 & 0.084 & -0.003 \\
\hline Adjusted $R^{2}$ & $* * * 0.178$ & $* * * 0.127$ & $* * * 0.118$ & $* * * 0.031$ & $* * * 0.037$ \\
\hline
\end{tabular}

Variables are significant at ${ }^{*} p<0.10,{ }^{* *} p<0.05$, and ${ }^{* * *} p<0.01$. ${ }^{\text {a }}$ Measured as dummy variable where 1 indicates full-time farmers and 0 denotes otherwise. ${ }^{b}$ Measured as dummy variable where farmer having primary source of income as agriculture and 0 denotes otherwise. ${ }^{c}$ Measured as dummy variable where 1 indicates farmers having successor and 0 denotes otherwise. ${ }^{d}$ Measured as dummy variable where 1 indicates farmers who sell their product to agents or middlemen and 0 denotes otherwise.

Institutional risk was professed to be more important for farmers near a main city with more cotton growing experience. However, farmers with large families were inclined to consider risks related to institutional constraints as less important. Similar findings were also observed by $[26,48]$. More educated farmers, farmers who considered agriculture as a primary source of income, and farmers with successors, considered financial risk to be key risk factor. Meuwissen et al. [41] also reported a tight financial situation as a risk factor more important for dairy farmers. Lastly, more educated farmers with a large agricultural farming area considered natural risk as a strong risk source.

\subsection{Drivers of Perceived/Implemented Risk Management Strategies}

The last step was to use the linear regression between the farm, farmers' characteristics, risk sources perception factors, and management strategy responses. The regression coefficients are given in Table 7 . Most of the chosen variables were highly significant. These regression models illustrated the relation among farmers' personal characteristics and risk management strategies applied/perceived to be most relevant at their farm. Farmers who perceived capital management as a vital risk management strategy were more educated farmers, farmers with more cotton growing experience, farmers with large families, farmers whose farms are their primary income source, and farmers who trained successors for their farms. However, distance from the main city was negatively related to the capital management strategy. More educated farmers perceived credit as an important risk management strategy. Nevertheless, farmers with more income considered credit as less important mainly due to the fact that they already had enough resources to run farm expenses. This behavior was similar to what was reported by Aditto et al. [54] in the case of developing economies. 
Table 7. The effect of different variables on risk management strategies.

\begin{tabular}{|c|c|c|c|c|c|}
\hline Independent Variables & $\begin{array}{c}\text { Capital } \\
\text { Management }\end{array}$ & Credit & $\begin{array}{l}\text { Research and } \\
\text { Development }\end{array}$ & $\begin{array}{l}\text { Information } \\
\text { Management }\end{array}$ & Diversification \\
\hline No. of years of education & $* * * 0.047$ & $* * 0.032$ & ** 0.028 & 0.009 & 0.010 \\
\hline Farming Experience & -0.005 & 0.010 & -0.008 & 0.010 & * -0.011 \\
\hline Age & -0.002 & -0.006 & 0.010 & * -0.013 & *0.013 \\
\hline Distance from main city & $* * *-0.027$ & -0.012 & 0.015 & * -0.018 & $* * 0.019$ \\
\hline Full-time farmer ${ }^{a}$ & -0.019 & -0.166 & $* *-0.251$ & $* * *-0.291$ & 0.004 \\
\hline Total farming area & -0.006 & 0.016 & -0.006 & 0.011 & 0.011 \\
\hline Cotton growing experience & $* * * 0.007$ & -0.001 & 0.005 & -0.008 & $* *-0.011$ \\
\hline Family size & $* * * 0.048$ & 0.002 & -0.013 & -0.015 & -0.011 \\
\hline Agriculture as primary source of income ${ }^{b}$ & $* * * 0.150$ & 0.040 & $* * * 0.749$ & * 0.191 & 0.145 \\
\hline Household monthly income & $1.826 \times 10^{-6}$ & * $-6.365 \times 10^{-6}$ & $3.717 \times 10^{-6}$ & $-4.042 \times 10^{-7}$ & $-3.520 \times 10^{-6}$ \\
\hline Having successor ${ }^{c}$ & $* * * 0.140$ & 0.098 & -0.008 & -0.059 & 0.064 \\
\hline Sale to agent or middleman ${ }^{d}$ & 0.037 & 0.077 & * -0.165 & -0.097 & -0.125 \\
\hline 1-Labour and Market information & $* * *-0.752$ & 0.035 & 0.075 & * 0.403 & $* * * 0.354$ \\
\hline 2-Production & $* * * 0.221$ & -0.054 & -0.073 & 0.015 & $* * * 0.160$ \\
\hline 3-Institutional & 0.013 & $* * * 0.268$ & $* * *-0.130$ & $* * * 0.157$ & $* * * 0.160$ \\
\hline 4-Financial & $* * *-0.087$ & $* * * 0.185$ & $* * * 0.242$ & $* * *-0.213$ & $* * *-0.321$ \\
\hline 5-Natural & $* * * 0.135$ & $* * *-0.116$ & 0.069 & $* * * 0.166$ & -0.005 \\
\hline Adjusted $\mathrm{R}^{2}$ & $* * * 0.829$ & $* * * 0.121$ & $* * * 0.178$ & $* * * 0.264$ & $* * * 0.34$ \\
\hline
\end{tabular}

Variables are significant at ${ }^{*} p<0.10,{ }^{* *} p<0.05$, and ${ }^{* * *} p<0.01$. ${ }^{a}$ Measured as dummy variable where 1 indicates full-time farmers and 0 denotes otherwise. ${ }^{b}$ Measured as dummy variable where farmer having agriculture as primary source of income and 0 denotes otherwise. ${ }^{\mathrm{c}}$ Measured as dummy variable where 1 indicates farmers having successor and 0 denotes otherwise. ${ }^{d}$ Measured as dummy variable where 1 indicates farmers who sell their product to agents or middlemen and 0 denotes otherwise.

Farmers with more education and those who consider agriculture as their primary income source labelled the research and development strategy as the most important factor when managing risk sources for their farms. Full-time farmers and farmers who sell their produce to middlemen did not think this strategy was important. The information management factor was professed to be a key strategy to reduce risks by farmers who depended on agriculture for their income/livelihood. Elderly people, farmers near the main city, and full-time farmers did consider this strategy important because older farmers are not progressive in their thinking. They mostly prefer to use older methods and neglect new information. Diversification was considered important by older farmers and farmers located near the city. These types of farmers focus on growing a variety of crops to reduce risk factors. However, farmers with more experience, especially in cotton growing, had a negative association with diversification. This association was confirmed by Lien et al. [26].

The regression models also pointed out that farmers' risk perception significantly swayed their economic behavior. For example, farmers who perceived labor and market information risk to be important risk sources showed a willingness to adopt strategies such as capital management, information management, and diversification. Production risk was associated with capital management and diversification strategies. Farmers who considered institutional risk factor a risk source focused on adopting credit strategies, as well as information management and diversification strategies. Financial risk source had a positive association with credit and research and development (R\&D) strategies. This was a comprehensive finding because when farmers do not have many resources to continue farm practices, they need credit to buy different inputs. Farmers who suffered from the 'natural' risk factor preferred strategies like capital management and information management because when farmers lose their production due to some natural factor, they need to adopt management strategies to establish themselves. A natural factor is beyond the control of farmers but loss can be minimized through proper management and obtaining prior information about the weather. From the literature review, it is known that a risk source can be managed through multiple strategies. Previous studies revealed that there is no 1:1 correspondence between risk source and management strategy $[25,56]$.

\subsection{Perceived Risk Sources, Mitigation Options, and Implications for Sustainable Agriculture}

The current study presents valuable insights for Pakistani agriculture. Risk source perceptionspecifically vis-à-vis the onset of any risky event and its impact-plays a significant role for 
farmers $[57,58]$. Such motivation is partly influenced by an economic motivation that safeguards belongings, including physical assets, crops, and livestock. The findings of this study posit such an intent among respondents who rightly pointed out various risk sources and their willingness to adapt to them. They further highlighted the major impetus of attaining credit availability, capital management, and the role of research and development in adopting risk management strategies. These findings were in line with Rawlani and Sovacool [59] and Pearce [60], each of whom showed that community participation in disaster (risk) mitigation involves an active link between institutions and communities for an early and proactive intervention that could lead to sustainability of farmers' livelihoods.

As a result, public and private institutions (such as community organization) develop the scope and success of adaptation strategies, providing timely incentives for community uplift among rural masses, boosting their confidence to mitigate risk, and instilling a sense of ownership among major stakeholders (farmers) (Grothmann and Reusswig, 2006; Poustie et al., 2014). This, in turn, has many ramification for nearby villagers who take the lead in adopting such mechanisms [61]. This study also sheds light on the role of education and information provision to rural inhabitants who exploit their potential to opt for a particular strategy to counter harmful risk source effects. Thus, they effectively achieve sustainability in a highly vulnerable sector such as agriculture.

Our findings also imply that, with increased awareness about risk sources and various socioeconomic influences, an informed policy intervention can play a key role in realizing sustainability, at least for grain productivity to ensure food provision at reasonable prices within Pakistan. In addition, new frameworks to achieve consistency in agricultural production at the local level and in regions with similar socioeconomic conditions can be chalked out. As discussed by Javaid and Flak [62], up-to-date information via effective institutional support would lead to increased input use efficiency (irrigation water use efficiency in particular) among small-scale family farms. On the other hand, risk mitigation through insurance, forward contracting, and spreading sales are shown to promote resilience of farm families that indirectly affects sustainable agriculture [63].

At the local level, adopting multiple measures to a range of risk sources is effective in a developing country like Pakistan that has exponential increases in population and urbanization despite a fledgling economic performance in recent years needed to overcome food insecurity, rural unemployment, and exorbitant inflation. Further, the country's growth rate has been sub-optimal $(0.38 \%$ for the year 2019-2020) [64]. This economic plight can no doubt be attributed to COVID-19; nevertheless, many other issues have contributed to marring this situation. However, agriculture has showed recent vitality, as its contribution is one-fifth of the country's GDP (around 19\%). With this contribution to the national economy, fostering the uptake of modern technology and building on the potential of the sector with prudent measures against external vagaries-be it institutional, natural, infrastructural, or socio-demographic - can stimulate the growth and wellbeing of the rural masses. Moreover, our findings imply that farming communities are well aware of past changes in the climate and other stimuli, and understand that future changes could likely cast negative impacts on their industry. Such a proactive implementation of farm management and adaptation strategies-most of which may have been adopted for other climatic variations, with additional farm productivity benefits [65] —seem highly promising in the context of the economy's recent ordinary performance.

\section{Summary and Conclusions}

In summary, we identified the significant risk sources faced by Pakistani farmers as follows: changes in agricultural policies, prices of farm equipment, lack of farmers' cooperation, supply of private capital, and human health problems. However, farmers perceived the following to be the most important risk sources: construction of small dams/turbine scheme, off-farm income sources, production diversity, updated market information, and trainings. Still, there was dissent among farmers with weak socioeconomic backgrounds; farmers' socioeconomic characteristics noticeably influenced their perception of risk sources and corresponding risk management strategies. In conclusion, farmers had no connection with processing units or a specific point to sell their produce without concerning agents. 
The trend of borrowing from middlemen and commission agents exploits farmers who need to survive on credit. Farmers have inadequate resources to store their produce in order to charge a decent price for their produce. Hence, it is suggested that there should be a standardized pricing system of agricultural inputs and outputs. Accessibility of farm credits should be given on flexible terms. The delivery of timely public and private extension services needs to be prioritized in view of this risky environment. Market information should be disseminated through Information and Communication Technologies (ICTs) to help farmers adopt preventive measures against various risks. The need to equip farmers with early information has been shown as a topmost preference among farmers, and thus it warrants dissemination of timely information to mitigate harmful effects of natural calamities.

In some developing countries like Pakistan, there is a need to streamline the role of the private sector to facilitate loaning, technical help, timely input provisions, and the dispersal of information by organizing farmer days or demonstration plots for the betterment of agricultural production. Further market systems for both inputs and outputs are not transparent. At input and output levels, farmers cannot obtain pricing information. Farm households do not have direct contact with processing units.

Author Contributions: Data curation: M.A.I. and A.A.; formal analysis: M.A.I.; investigation: S.A.A.N. and M.R.; resources: S.A.A.N. and A.A.; Software: A.A. and A.S.; validation: A.S. and M.A.I.; visualization: M.R., U.I.A.; writing-review and editing: A.A., M.R., M.A.I., and U.A.I. All authors have read and agreed to the published version of the manuscript.

Funding: This research received no external funding.

Acknowledgments: The authors are very grateful to the reviewers for their valuable comments.

Conflicts of Interest: The authors declare no conflict of interest.

\section{References}

1. Khan, N.A.; Gao, Q.; Iqbal, M.A.; Abid, M. Modeling food growers' perceptions and behavior towards environmental changes and its induced risks: Evidence from Pakistan. Environ. Sci. Pollut. Res. 2020, 27, 20292-20308. [CrossRef] [PubMed]

2. Abid, M.; Scheffran, J.; Schneider, U.A.; Ashfaq, M. Farmers' perceptions of and adaptation strategies to climate change and their determinants: The case of Punjab province, Pakistan. Earth Syst. Dyn. 2015, 6, 225-243. [CrossRef]

3. Ali, A.; Erenstein, O. Assessing farmer use of climate change adaptation practices and impacts on food security and poverty in Pakistan. Clim. Risk Manag. 2017, 16, 183-194. [CrossRef]

4. Korir, L.K. Risk management among agricultural households and the role of off-farm investments in Uasin Gishu County, Kenya. Ph.D. Thesis, Egerton University, Njoro, Kenya, 2011. [CrossRef]

5. Jaffee, S.; Siegel, P.; Andrews, C. Rapid agricultural supply chain risk assessment: A conceptual framework. Agric. Rural Dev. Discuss. Pap. 2010, 47, 1-64.

6. Hardaker, J.B. Some Issues in Dealing with Risk in Agriculture; University of New England, Graduate School of Agricultural and Resource Economics: Armidale, Australia, 2000; ISBN 1863896678.

7. Hall, D.C.; Knight, T.O.; Coble, K.H.; Baquet, A.E.; Patrick, G.F. Analysis of beef producers' risk management perceptions and desire for further risk management education. Rev. Agric. Econ. 2003, 25, 430-448. [CrossRef]

8. Koesling, M.; Ebbesvik, M.; Lien, G.; Flaten, O.; Valle, P.S.; Arntzen, H. Risk and risk management in organic and conventional cash crop farming in Norway. Food Econ. Acta Agric. Scand. Sect. C 2004, 1, $195-206$. [CrossRef]

9. Iqbal, M.A.; Ping, Q.; Abid, M.; Abbas, A.; Bashir, M.K.; Ullah, R. Extent and determinants of rural poverty in pakistan: Role of adopting risk management strategies. J. Anim. Plant Sci. 2018, 28, 1835-1845.

10. Sulewski, P.; Kłoczko-Gajewska, A.; Sroka, W. Relations between agri-environmental, economic and social dimensions of farms' sustainability. Sustainability 2018, 10, 4629. [CrossRef]

11. Rasure, K.A. Sustainable Agricultural Development; Oxford Book Company: New Delhi, India, 2010.

12. Hardaker, J.B.; Richardson, J.W.; Lien, G.; Schumann, K.D. Stochastic efficiency analysis with risk aversion bounds: A simplified approach. Aust. J. Agric. Resour. Econ. 2004, 48, 253-270. [CrossRef] 
13. Pretty, J. Agricultural sustainability: Concepts, principles and evidence. Philos. Trans. R. Soc. B Biol. Sci. 2008, 363, 447-465. [CrossRef]

14. Hazell, P.; Wood, S. Drivers of change in global agriculture. Philos. Trans. R. Soc. B Biol. Sci. 2008, 363, 495-515. [CrossRef] [PubMed]

15. Ellis, F. The determinants of rural livelihood diversification in developing countries. J. Agric. Econ. 2000, 51, 289-302. [CrossRef]

16. Hayati, D. A Literature Review on Frameworks and Methods for Measuring and Monitoring Sustainable Agriculture; Technical Report; FAO: Rome, Italy, 2017.

17. Pennings, J.M.E.; Isengildina-Massa, O.; Irwin, S.H.; Garcia, P.; Good, D.L. Producers' complex risk management choices. Agribusiness 2008, 24, 31-54. [CrossRef]

18. Rizwan, M.; Qing, P.; Saboor, A.; Iqbal, M.A.; Nazir, A. Production risk and competency among categorized rice peasants: Cross-sectional evidence from an emerging country. Sustainability 2020, 12, 3770. [CrossRef]

19. Okunmadewa, F. Risk, Vulnerability in Agriculture: Concept and Context; A paper Presented at Staff Seminar; Department of Agricultural Economics, University of Ibadan: Ibadan, Nigeria, 2003.

20. Ayinde, O.E. Effect of socio-economic factors on risk behaviour of farming households: An empirical evidence of small-scale crop producers in Kwara state. Niger. Agric. J. 2008, 3, 447-523.

21. Holzmann, R.; Jørgensen, S. Social risk management: A new conceptual framework for social protection, and beyond. Int. Tax Public Financ. 2001, 8, 529-556. [CrossRef]

22. Arshad, M.; Kächele, H.; Krupnik, T.J.; Amjath-Babu, T.S.; Aravindakshan, S.; Abbas, A.; Mehmood, Y.; Müller, K. Climate variability, farmland value, and farmers' perceptions of climate change: Implications for adaptation in rural Pakistan. Int. J. Sustain. Dev. World Ecol. 2017, 24, 532-544. [CrossRef]

23. Mahmood, N.; Arshad, M.; Kaechele, H.; Shahzad, M.F.; Ullah, A.; Mueller, K. Fatalism, climate resiliency training and farmers' adaptation responses: Implications for sustainable rainfed-wheat production in Pakistan. Sustainability 2020, 12, 1650. [CrossRef]

24. Akcaoz, H.; Ozkan, B. Determining risk sources and strategies among farmers of contrasting risk awareness: A case study for Cukurova region of Turkey. J. Arid. Environ. 2005, 62, 661-675. [CrossRef]

25. Flaten, O.; Lien, G.; Koesling, M.; Valle, P.S.; Ebbesvik, M. Comparing risk perceptions and risk management in organic and conventional dairy farming: Empirical results from Norway. Livest. Prod. Sci. 2005, 95, 11-25. [CrossRef]

26. Lien, G.; Flaten, O.; Jervell, A.M.; Ebbesvik, M.; Koesling, M.; Valle, P.S. Management and risk characteristics of part-time and full-time farmers in Norway. Rev. Agric. Econ. 2006, 28, 111-131. [CrossRef]

27. Rizwan, M.; Deyi, Z.; Nazir, A.; Osti, R.; Ahmed, U.I.; Zhu, Y.; Iqbal, M.A. Risk perceptions and management strategies of rice growing households: Evidence from a developing country. J. Appl. Environ. Biol. Sci. 2017, 7, 15-26.

28. Ikerd, J. Understanding and managing the multi-dimensions of sustainable agriculture. In Proceedings of the Southern Region Sustainable Agriculture Professional Development Program Workshop, SARE regional training consortium, Gainesville, FL, USA, 15 January 1997.

29. Ciegis, R.; Ramanauskiene, J.; Martinkus, B. The concept of sustainable development and its use for sustainability scenarios. Eng. Econ. 2009, 62, 28-37.

30. Wheeler, T.; Reynolds, C. Predicting the risks from climate change to forage and crop production for animal feed. Anim. Front. 2013, 3, 36-41. [CrossRef]

31. Faisal, I.M.; Parveen, S. Food security in the face of climate change, population growth, and resource constraints: Implications for Bangladesh. Environ. Manag. 2004, 34, 487-498. [CrossRef] [PubMed]

32. Brown, H.C.P.; Sonwa, D.J. Rural local institutions and climate change adaptation in forest communities in Cameroon. Ecol. Soc. 2015, 20. [CrossRef]

33. Keshavarz, M.; Karami, E. Institutional adaptation to drought: The case of Fars Agricultural Organization. J. Environ. Manag. 2013, 127, 61-68. [CrossRef]

34. Raymond, C.M.; Spoehr, J. The acceptability of climate change in agricultural communities: Comparing responses across variability and change. J. Environ. Manag. 2013, 115, 69-77. [CrossRef]

35. Wang, W.; Ertsen, M.W.; Svoboda, M.D.; Hafeez, M. Propagation of drought: From meteorological drought to agricultural and hydrological drought. Adv. Meteorol. 2016, 2016, 1-5. [CrossRef]

36. GoP. Statitical Appendix, Agriculture, Pakistan Economic Survey; Ministry of Finance: Islamabad, Pakistan, 2019. 
37. Abid, M.; Schilling, J.; Scheffran, J.; Zulfiqar, F. Climate change vulnerability, adaptation and risk perceptions at farm level in Punjab, Pakistan. Sci. Total Environ. 2016, 547, 447-460. [CrossRef]

38. Rizwan, M.; Deyi, Z.; Nazir, A.; Osati, R.; Traore, L.; Sargani, G.R. Determinants and choices of off-farm work among rice farmers in a developing country. J. Anim. Plant Sci. 2017, 27, 1993-2002.

39. Government of Punjab (GOPun). Punjab Agricultural Department Official Site. Available online: http: //www.agripunjab.gov.pk/overview (accessed on 3 November 2016).

40. Poon, K.; Weersink, A. Factors affecting variability in farm and off-farm income. Agric. Financ. Rev. $2011,71$. [CrossRef]

41. Meuwissen, M.P.M.; Huirne, R.B.M.; Hardaker, J.B. Risk and risk management: An empirical analysis of Dutch livestock farmers. Livest. Prod. Sci. 2001, 69, 43-53. [CrossRef]

42. Ahmed, N.; Rao, K.R. Orthogonal Transforms for Digital Signal Processing; Springer Science \& Business Media: Berlin/Heidelberg, Germany, 2012; ISBN 364245450X.

43. Badar, H.; Ghafoor, A.; Adil, S.A. Factors affecting agricultural production of Punjab (Pakistan). Pak. J. Agric. Sci. 2007, 44, 506-510.

44. Shafique, M. Supply Response of Major Crops in Different Agro-Ecological Zones in Punjab 2005. Available online: https://www.semanticscholar.org/paper/SUPPLY-RESPONSE-OF-MAJOR-CROPS-INDIFFERENT-ZONES-Shafique/bed9fd70170622e6b4f90d5b1560a49f62541fcc (accessed on 2 March 2020).

45. Sulewski, P.; Kłoczko-Gajewska, A. Farmers' risk perception, risk aversion and strategies to cope with production risk: An empirical study from Poland. Stud. Agric. Econ. 2014, 116, 140-147. [CrossRef]

46. Gebreegziabher, K.; Tadesse, T. Risk perception and management in smallholder dairy farming in Tigray, Northern Ethiopia. J. Risk Res. 2014, 17, 367-381. [CrossRef]

47. Hayran, S. Perceptions of wheat producers towards risk and risk management strategies: A case study from Turkey. Ciência Rural 2019, 49, 49. [CrossRef]

48. Ahsan, D.A. Farmers' motivations, risk perceptions and risk management strategies in a developing economy: Bangladesh experience. J. Risk Res. 2011, 14, 325-349. [CrossRef]

49. Bergfjord, O.J. Risk perception and risk management in Norwegian aquaculture. J. Risk Res. 2009, 12, 91-104. [CrossRef]

50. Luik, P.; Taimalu, M.; Kalk, K.; Täht, K. Validity and reliability of two instruments to measure reflection: A confirmatory study. TRAMES: J. Humanit. Soc. Sci. 2014, 18, 121. [CrossRef]

51. Akcaoz, H.; Kizilay, H.; Ozcatalbas, O. Risk management strategies in dairy farming: A case study in Turkey. J. Anim. Vet. Adv. 2009, 8, 949-958.

52. Hair, J.F.J.; Black, W.C.; Babin, B.J.; Anderson, R.E. Multivariate Data Analysis, 7th ed.; Prentice Hall: New Jersey, NJ, USA, 2010.

53. Qasim, M. Determinants of Farm Income and Agricultural Risk Management Strategies: The Case of Rain-Fed Farm Households in Pakistan's Punjab; Kassel University Press GmbH: Kassel, Germany, 2012; Volume 3, ISBN 3862192989.

54. Aditto, S.; Gan, C.; Nartea, G.V. Sources of Risk and Risk Management Strategies: The Case of Smallholder Farmers in a Developing Economy; INTECH Open Access Publisher: London, UK, 2012; ISBN 953510747X.

55. Ahsan, D.A.; Roth, E. Farmers' perceived risks and risk management strategies in an emerging mussel aquaculture industry in Denmark. Mar. Resour. Econ. 2010, 25, 309-323. [CrossRef]

56. Patrick, G.F.; Musser, W.N. Sources of and responses to risk: Factor analyses of large-scale US cornbelt farmers. Risk Manag. Strateg. Agric. 1997, 7, 45-53.

57. Kreibich, H.; Christenberger, S.; Schwarze, R. Economic motivation of households to undertake private precautionary measures against floods. Nat. Hazards Earth Syst. Sci. 2011, 11, 309-321. [CrossRef]

58. Kellens, W.; Zaalberg, R.; Neutens, T.; Vanneuville, W.; De Maeyer, P. An analysis of the public perception of flood risk on the Belgian coast. Risk Anal. 2011, 31, 1055-1068. [CrossRef]

59. Rawlani, A.K.; Sovacool, B.K. Building responsiveness to climate change through community based adaptation in Bangladesh. Mitig. Adapt. Strateg. Glob. Chang. 2011, 16, 845-863. [CrossRef]

60. Pearce, L. Disaster management and community planning, and public participation: How to achieve sustainable hazard mitigation. Nat. Hazards 2003, 28, 211-228. [CrossRef]

61. Swallow, B.M.; Woudyalew, M. Evaluating willingness to contribute to a local public good: Application of contingent valuation to tsetse control in Ethiopia. Ecol. Econ. 1994, 11, 153-161. [CrossRef] 
62. Javaid, A.; Falk, T. Incorporating local institutions in irrigation experiments: Evidence from rural communities in Pakistan. Ecol. Soc. 2015, 20, 28. [CrossRef]

63. Velandia, M.; Rejesus, R.M.; Knight, T.O.; Sherrick, B.J. Factors affecting farmers' utilization of agricultural risk management tools: The case of crop insurance, forward contracting, and spreading sales. J. Agric. Appl. Econ. 2009, 4, 107-123. [CrossRef]

64. GoP. Pakistan Economic Survey 2018-19; Ministry of Finance: Islamabad, Pakistan, 2020.

65. Silvestri, S.; Bryan, E.; Ringler, C.; Herrero, M.; Okoba, B. Climate change perception and adaptation of agro-pastoral communities in Kenya. Reg. Environ. Chang. 2012, 12, 791-802. [CrossRef]

Publisher's Note: MDPI stays neutral with regard to jurisdictional claims in published maps and institutional affiliations.

(C) 2020 by the authors. Licensee MDPI, Basel, Switzerland. This article is an open access article distributed under the terms and conditions of the Creative Commons Attribution (CC BY) license (http://creativecommons.org/licenses/by/4.0/). 